\title{
Adoniev Y., Naidysh A., Vereschaga V.

DEVELOPMENT OF GENERALIZED
TECHNIQUE FOR FORMATION OF
CHARACTERISTIC FUNCTIONS AND
BALYUBA-NAIDYSH COORDINATES IN THE
COMPOSITION METHOD OF GEOMETRICAL
MODELING

Об'єктом дослідження є техніка формування характеристичних функиій та координат Балюби-Найдиша (БН-координат) у композиційному методі геометричного моделювання. Існуючі методи моделювання економічних, технологічних та будь-яких інших процесів на реальних об'єктах є доволі складними, зі значними обмеженнями по кількості вхідних факторів.

Одним з найбільш проблемних місиь є складність та вузька сфера застосування кожного з існуючих методів моделювання, що стримує їх розповсюдження та практичне впровадження на реальних суб'єктах господарювання. Звідси випливає необхідність розробки універсального методу моделювання багатофакторних систем. Найбільш близьким до иьього є композиційний метод геометричного моделювання (КМГМ), універсальність якого забезпечується, в периу чергу, завдяки використанню власної техніки формування характеристичних функиій та БН-координат.

Застосування у КМГМ кривих Балюби (Б-кривих), побудованих у БН-координатах, надає значні переваги КМГМ. Одно-, дво-, трипараметрична Б-крива може розглядатися у п-вимірному євклідовому просторі $E^{n}$. В результаті цвого КМГМ може застосовуватися для розв'язання задач у n-вимірному просторі, а результат розв'язку може бути розкладений на п одновимірних проекцій, на яких легко проводити аналіз розв'язку. Це може застосовуватися, зокрема, в інформаційних системах підтримки управлінських рішень. Особливістю Б-кривих є те, що БН-координати $p(t) ; q(t) ; r(t)$ являють собою ї̈ параметричну модель, яка $\epsilon$ сталою. Застосовуючи безліч варіантів зміни точок можемо отримувати безліч варіантів Б-кривих, що $\epsilon$ важливим для проведення комп'ютерних експериментів з метою підвищення адекватності побудованої геометричної моделі.

Принципом формування характеристичних функиій є операція множення параметрів і штучно призначених коефічієнтів. В результаті визначення добуток у вузлових точках перетворюється у нуль або одиницю, а у проміжках між вузловими точками - змінюється від нуля до одиниці. Кількість множників характеристичної функиї дорівнює кількості вузлових точок, які інтерполює характеристична функція. БН-координати однієї Б-кривої утворюють систему взаємопов'язаних дробово-раціональних функцій.

Таким чином, розроблена узагальнююча техніка алгебраїчного формування характеристичних функцій, визначено перехід від характеристичних функиій до БН-координат для інтерполячї трвох точок. Застосована тут техніка може бути використана і для геометричної інтерполяції чотирьох і більше точок. Можливість збільшення кількості вихідних точок геометричної фігури для БН-інтерполяиій розширює можливості моделей багатофакторних прочесів, систем, тощо.

Ключові слова: точкове числення Балюби-Найдиша, формування характеристичних функиій, параметричний зв'язок, багатофакторне моделювання.

\section{Introduction}

The development of information technology requires new methods of modeling situations and processes that adequately reflect economic activity. That is, an automated workplace that allows to simulate daily situations and processes at the site must be directly close to the person making a decision about the effective conduct of economic activities. To do this, the method of geometric modeling, the resulting model and software implementation should be easy to use, easy to adjust to the activities of the business entity and use computers of common capacities.
The circle of tasks that are daily solved by business entities is quite large and diverse and, at the same time, they are diverse, complex, multifactorial, multilayered, dynamic, have heterogeneous constituent elements and, as a rule, are defined in multidimensional parameter spaces. The solution of these problems requires a large number of structurally and functionally different methods. However, all these requirements for the model's capabilities should be based on one method of geometric modeling (MGM), which will ensure the universality of models and their ease of use in practice. At the moment, only the composite method of geometric modeling (CMGM), based on 
the point-like numerous Balyuba-Naidysh (BN-calculus), corresponds to the highest degree to the requirements set forth above. One of the main stages of CMGM in the construction of the model is the formation of characteristic functions and on their basis the determination of BN-coordinates.

The creation of techniques for the formation of characteristic functions and the determination of $B N$-coordinates on their basis is an actual task of global interpolation, because it eliminates the need to solve systems of linear equations for determining interpolation coefficients. Due to this, the solution of the problem is simplified and the resource costs for solving it are reduced. The urgency of applying $B$-curves is also determined by the fact that their projection on the coordinate axis occurs without changing the values of the $B N$-coordinates. This is important for a deeper analysis using models built on $B$-curves that occur in a system or facility. Thus, the development of a generalized technique for the formation of characteristic functions and $\mathrm{BN}$-coordinates is topical.

\section{The object of research and its technological audit}

The object of research is the technique of forming characteristic functions and the Balyuba-Naidysh coordinates in the composite method of geometric modeling.

The modeling of economic, technological and any other processes that occur on real objects is complex and multifactorial. Hence the existing methods and models are quite complex, with significant limitations on the number of incoming factors.

One of the most problematic places is the complexity and narrow scope of each of the existing modeling methods, restrains their distribution and practical implementation on real business entities. Hence there is a need to develop a universal method for modeling multifactor systems. The closest to this is the composite method of geometric modeling, which universality is provided, first of all, by using its own technique of forming characteristic functions and $\mathrm{BN}$-coordinates.

\section{The aim and objectives of research}

The aim of the research is development of a generalized technique for the formation of characteristic functions and the Balyuba-Naidysh coordinates (BN-coordinates) in the composite geometric modeling method (CMGM).

To achieve this aim, it is necessary to perform the following tasks:

1. To form the principles of the formation of characteristic functions in the CMGM.

2. To determine the form of the function, forms a $B N$ coordinate.

3. To determine the nature and properties of $B N$-coordinates of the B-curve.

\section{Research of existing solutions of the problem}

In order to develop a universal method of geometric modeling that would satisfy all the requirements for the model, let's consider the main directions and existing approaches to the geometric modeling of multifactor systems.
The most difficult in geometric modeling is the design and reproduction of surfaces of complex shapes. Such surfaces, as a rule, must satisfy many, predefined, conditions [1,2]. Even more complex is the construction of curves and surfaces with predetermined integrative characteristics and metric relations [3].

Scientific development $[4,5]$ plays an important role in shaping the directions of scientific research in Ukraine to restore surfaces with complex initial requirements. The most known methods of global interpolation of one-dimensional geometric figures of curves are the methods described in $[6,7]$. Questions of local interpolation and the use of complex curves are given attention in [8].

However, despite the considerable scientific potential in the field of modeling multifactor systems, currently existing methods do not meet all the requirements of practical application, in particular, simplicity and universality. The compositional method of geometric modeling (CMGM), based on the point-like Balyuba-Naidysh [9, 10], is closer to fulfilling all the conditions formulated. The key moment that ensures the universality of this method is the technique for the formation of characteristic functions and $B N$-coordinates. Thus, the development of a generalized technique for the formation of characteristic functions and $B N$-coordinates is promising.

\section{Methods of research}

In the course of research, scientific methods are used: - method of analysis when studying existing methods of multifactor modeling;

- method of classification when identifying typical problems of modeling processes on real objects as multifactor systems;

- methods of the Balyuba-Naidysh point calculation are used as a basis for the developed technique for the formation of characteristic functions and $B N$-coordinates; - method of generalization in determining the universal properties of the model obtained.

\section{Research results}

The composite method of geometric modeling (CMGM) of multifactor systems is developed on the basis of the BalyubaNaidysh point calculation ( $B N$-calculus). In CMGM, the key to the construction of a multifactor model is the formation of the characteristic functions and Balyuba-Naidysh coordinates ( $B N$-coordinates). The main advantage of CMGM is its versatility. This is achieved, first of all, thanks to the developed generalizing technique of algebraic formation of characteristic functions and $\mathrm{BN}$-coordinates. The essence of this technique can be discerned as follows. Let it be necessary to interpolate three points $A, C, B$ (Fig. 1).

A characteristic function for three points $A, C, B$ will be called functions $p(t), q(t), r(t)$ такі such that:

For point $A: p_{A}\left(t_{A}\right)=1 ; p_{A}\left(t_{C}\right)=0 ; p_{A}\left(t_{B}\right)=0$;

For point $C$ : $q_{C}\left(t_{A}\right)=0 ; q_{C}\left(t_{C}\right)=1 ; q_{C}\left(t_{B}\right)=0$;

For point $B: r_{B}\left(t_{A}\right)=0 ; r_{B}\left(t_{C}\right)=0 ; r_{B}\left(t_{B}\right)=1$.

The value of the parameter $t$ for the initial points $A$, $C, B$ will be determined by the ratio of the corresponding differences in the coordinates $x_{i}$ of these output points:

$$
t_{A}=\frac{x_{A}-x_{A}}{x_{B}-x_{A}}=0 ; t_{C}=\frac{x_{C}-x_{A}}{x_{B}-x_{A}} ; t_{B}=\frac{x_{B}-x_{A}}{x_{B}-x_{A}}=1 .
$$




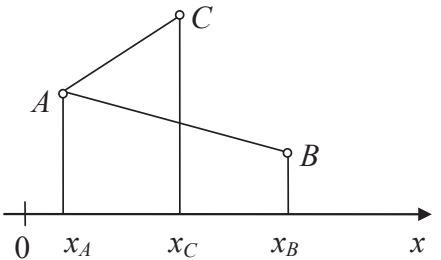

Fig. 1. The scheme for determining the $t_{i}$ parameter

Thus, the arc of the Balyuba curve ( $B$-curve) [11] interpolates the original points $A, C, B$, in accordance with (1), in the range of the parameter $0 \leq t \leq 1$ values, since at point $A$ the parameter $t_{A}=0$, and at point $B$ the parameter $t_{B}=1$.

$B$-curve is the curve $M$, which has the equation:

$$
\begin{aligned}
& M=A \frac{p_{A}(t)}{\sigma}+C \frac{q_{C}(t)}{\sigma}+B \frac{r_{B}(t)}{\sigma}, \\
& 0 \leq t \leq 1,
\end{aligned}
$$

where $p_{A}(t) / \sigma ; q_{C}(t) / \sigma ; r_{B}(t) / \sigma$ is called $B N$-coordinates, the sum of which is:

$$
\frac{p_{A}(t)}{\sigma}+\frac{q_{C}(t)}{\sigma}+\frac{r_{B}(t)}{\sigma}=1
$$

where $\sigma=p_{A}(t)+q_{C}(t)+r_{B}(t)$.

Curve (2), for the fulfillment of these conditions, will pass through the output points $A, C, B$.

Let's show the technique for the formation of characteristic functions $p_{A}(t) ; q_{C}(t) ; r_{B}(t)$.

1. Define the characteristic function $p(t)$ for point $A$.

The characteristic functions will be formed as a product, which multipliers are expressions, transform the product the characteristic function into zero or one, according to the predetermined values of the parameter $t$.

Let's consider a formation $p_{A}\left(t_{B}\right)$ that should be zero. The parameter $\bar{t}$, complemented by $t$ to 1 at point $B$ is equal to zero: $\bar{t}=1-t_{B}=0$. So, let's choose $p_{A}\left(t_{B}\right)=\bar{t}$.

Thus, $\bar{t}$ is the first factor of the desired characteristic function $p(t)$, but its value at the point $C$ will not be zero, but will have values:

$$
\bar{t}_{C}=\left(1-\frac{x_{C A}}{x_{B A}}\right) \text {. }
$$

Then, to convert the expression:

$$
\left(1-\frac{x_{C A}}{x_{B A}}\right)
$$

to zero, it must be multiplied by the second factor, which at $t=t_{C}$ would equal zero that is:

$$
p_{C}(t)=\bar{t} \cdot \alpha,
$$

where $\alpha=0$ - the artificially created multiplier equal to zero for $t=t_{C}$.

For example, let's form the simplest possible, the second factor in the form:

$$
\alpha=\bar{t}-k_{C p} t
$$

where $k_{C p}=\bar{t}_{C} / t_{C}-$ a constant value determined for point $C$; $t_{C}=x_{C A} / x_{B A}-$ the value of the parameter $t$ at point $C$.
Then, taking into account (4), the expression (3) for the required characteristic function has the following form:

$$
p_{C}(t)=\bar{t} \cdot\left(\bar{t}-k_{C p} t\right) .
$$

Finally, let's consider the formation of the expression of the characteristic function for point $A$, in which, for the value of the parameter $t=t_{A}=0$, its expression value $p_{A}\left(t_{A}\right)=1$ must be equal to one. To do this, let's calculate the function (5) for the parameter $t_{A}=0$ value, for which $\bar{t}_{A}=1-0=1$ :

$$
p_{A}\left(t_{A}\right)=\bar{t}_{A}\left(\bar{t}_{A}-k_{C p} t_{A}\right)=1 \cdot\left(1-k_{C p} \cdot 0\right)=1 .
$$

Thus, with (6) it follows that (5) also satisfies the requirement for the expression $p_{A}(t)=1$ at the point $A$ with respect to the value of the parameter $t_{A}=0$.

Whence, the final expression of the characteristic function $p(t)$ near the point $A$, in the point equation (2), will have the form:

$$
p(t)=\bar{t} \cdot\left(\bar{t}-k_{C p} t\right)
$$

2. Let's define the characteristic function $q(t)$, which is a multiplier for the point $C$ from the point equation (2).

At point $A$, the characteristic function $q_{A}(t)$ must equal zero by the value of the parameter $t=t_{A}$. Since there is a parameter $t_{A}=0$ at point $A$, the expression that will be the first factor for the characteristic function will have the form:

$$
q_{A}(t)=t .
$$

Next, in the second step, let's define for the characteristic function an expression $q_{B}(t)$ for the point $B$ at which $q_{B}(t)$ must be zero and, at the same time, contain the first factor (8). Since the value of the parameter $\bar{t}_{B}=0$ at point $B$, the expression $q_{B}(t)$ for point $B$ will look like:

$$
q_{B}(t)=t \cdot \bar{t}
$$

Finally, in the third step, let's define the expression $q_{C}(t)$ for the point $C$, in which it must equal unity by the value of the parameter $t=t_{C}$. Let's expand (9), substituting the parameters $t_{C}$ and $\bar{t}_{C}$,

$$
q_{C}\left(t_{C}\right)=t_{C} \cdot \bar{t}_{C}=\frac{x_{C A}}{x_{B A}} \cdot\left(1-\frac{x_{C A}}{x_{B A}}\right) \neq 1 .
$$

The expression for the right-hand side of (10) is not equal to 1 . However, the requirement remains, at the point $C$ by the value of the parameter $t=t_{C}, q_{C}\left(t_{C}\right)=1$. To fulfill this requirement, let's introduce the coefficient $k_{C q}$ in equation (10), then it is possible to write:

$$
\frac{x_{C A}}{x_{B A}}\left(1-\frac{x_{C A}}{x_{B A}}\right) \cdot k_{C q}=1,
$$

so

$$
k_{C q}=\frac{1}{\frac{x_{C A}}{x_{B A}}\left(1-\frac{x_{C A}}{x_{B A}}\right)}=\frac{1}{t_{C} \bar{t}_{C}} .
$$


Then, taking (11) as the third factor, the final expression of the characteristic function $q(t)$ will have the form:

$$
q(t)=k_{C q} \cdot \bar{t} \bar{t}=\frac{t \bar{t}}{t_{C} \bar{t}_{C}} .
$$

3. Let's consider the sequence of formation of the characteristic function $r(t)$, in the point equation (2) is a factor for point $B$.

Let's choose:

$$
r_{A}(t)=t
$$

since at point $A$ the parameter $t=t_{A}=0$.

In the second step, it is necessary to form an expression $r_{C}(t)$ for the characteristic function, taking into account the already determined first factor $r_{A}(t)=t$ from (13). However, the parameter $t$ at the point $C$ is not zero:

$$
t_{C} \neq 0 ; \rightarrow t_{C}=\frac{x_{C A}}{x_{B A}},
$$

then

$$
\bar{t}_{C}=\left(1-\frac{x_{C A}}{x_{B A}}\right) .
$$

The second factor must depend on the parameter and simultaneously equal to zero, so let's define it from the following equation:

$$
\left(\bar{t}-k_{C r} t\right)=0 \rightarrow k_{C r}=\frac{\bar{t}_{C}}{t_{C}} .
$$

Then, the second factor of the expression $r_{C}(t)$ for the characteristic function $r(t)$ will be zero by the value of the parameter $t=t_{C}$. Taking into account what has been said, let's write:

$$
r_{C}(t)=t\left(\bar{t}-k_{C r} t\right) .
$$

Third step, let's form the expression $r_{B}(t)$ of the characteristic function $r(t)$, which must be equal to $1 r_{B}(t)=1$. To begin with, in the equation (15) let's substitute the value of the parameter $t=t_{B}$ :

$$
\begin{aligned}
& r_{C}\left(t_{B}\right)=t_{B}\left(\bar{t}_{B}-k_{C r} t_{B}\right)=1 \cdot\left(0-k_{C r} \cdot 1\right)= \\
& =1 \cdot\left(-k_{C r} \cdot 1\right)=-k_{C r} .
\end{aligned}
$$

Taking into account that the last entry, let's define the last expression of the characteristic function $r_{B}(t)$, which will be equal to the characteristic function $r(t)$ itself, that is:

$$
r(t)=r_{B}(t)=r_{C}(t) \cdot\left(-\frac{1}{k_{C r}}\right)=-\frac{1}{k_{C r}} \cdot t \cdot\left(\bar{t}-k_{C r} t\right) .
$$

Let's combine the results of the algebraic formation of characteristic functions $p(t) ; q(t) ; r(t)$ in Table 1 .

The characteristic functions that ensure the conditions for the passage of the $B$-curve (2) through the original points $A$, $C$ and $B$ are written in the last row of Table 1 . However, these characteristic functions $p(t) ; q(t) ; r(t)$ is not consistent and therefore does not represent $B N$-coordinates. In order to function $p(t) ; q(t) ; r(t)$ become $B N$-coordinates, it is necessary to fulfill one more sufficient condition:

$$
p(t)+q(t)+r(t)=1
$$

In most cases:

$$
p(t)+q(t)+r(t) \neq 1 \text {. }
$$

In order that inequality (18) becomes equality we introduce the matching factor $\alpha$ :

$$
\alpha=\frac{1}{p(t)+q(t)+r(t)} .
$$

So

$\alpha[p(t)+q(t)+r(t)]=1$.

\begin{tabular}{|c|c|c|c|c|c|c|}
\hline \multirow{2}{*}{ № } & \multirow{2}{*}{ Points } & \multicolumn{3}{|c|}{ Parameters } & \multicolumn{2}{|c|}{ Characteristic functions } \\
\hline & & $t$ & $\bar{t}$ & $p(t)$ & $q(t)$ & $r(t)$ \\
\hline 1 & $A$ & 0 & 1 & $p_{A}(t)=\bar{t} \cdot\left(\bar{t}-k_{L p} t\right)$ & $q_{A}(t)=t$ & $\Gamma_{A}(t)=t$ \\
\hline 2 & C & $t_{C}$ & $\overline{t_{C}}=1-t_{C}$ & $p_{C}(t)=\bar{t} \cdot\left(\bar{t}-k_{C p} t\right)$ & $q_{C}(t)=\frac{t \bar{t}}{t_{C} \overline{t_{C}}}$ & $\Gamma_{C}(t)=t \cdot\left(\bar{t}-k_{L r} t\right)$ \\
\hline 3 & $B$ & 1 & 0 & $p_{B}(t)=\bar{t}$ & $q_{B}(t)=t \bar{t}$ & $\Gamma_{B}(t)=-\frac{1}{k_{L r}} \cdot t \cdot\left(\bar{t}-k_{L r} t\right)$ \\
\hline 4 & - & - & - & $p(t)=\bar{t} \cdot\left(\bar{t}-k_{C p} t\right)$ & $q(t)=\frac{t \bar{t}}{t_{C} \bar{t}_{C}}$ & $\Gamma(t)=-\frac{1}{k_{C r}} \cdot t \cdot\left(\bar{t}-k_{C r} t\right)$ \\
\hline
\end{tabular}

Let's open (20) and obtain:

$$
\bar{t}\left(\bar{t}-k_{C p} \cdot t\right) \cdot \alpha+\frac{t \bar{t} \cdot \alpha}{t_{C} \bar{t}_{C}}-\frac{\alpha}{k_{C r}} \cdot t\left(\bar{t}-k_{C r} \cdot t\right)=1 .
$$

In equation (21), which consists of three terms:

$$
\bar{t}\left(\bar{t}-k_{C p} \cdot t\right) \cdot \alpha ; \quad \frac{t \bar{t} \cdot \alpha}{t_{C} \bar{t}_{C}} ; \quad-\frac{\alpha}{k_{C r}} \cdot t\left(\bar{t}-k_{C r} \cdot t\right),
$$

which are multipliers for the point equation (2). Let's write it taking into account (21):

$$
M=A \cdot \bar{t}\left(\bar{t}-k_{C p} \cdot t\right) \cdot \alpha+C \frac{t \bar{t}}{t_{C} \bar{t}_{C}} \cdot \alpha-B \frac{\alpha}{k_{C p}} \cdot t\left(\bar{t}-k_{C p} \cdot t\right) .
$$

Table 1

Elements-factors of characteristic functions and characteristic functions 
This point equation of the current point $M$, which is taken through three $B N$-coordinates on the plane, relative to the basic (output) points $A, C, B$. These $B N$-coordinates provide interpolation of points $A, C, B$.

Characteristic functions $p(t) ; q(t) ; r(t)$, shown in the last row of Table 1 , are the simplest, but are not the only ones. There are many such characteristic functions. So, as a consequence, with respect to the basis points $A, C, B$, it is possible to define the set of $B N$-coordinates with the help of which the geometric interpolation of the initial points $A, C, B$ will be performed. The presence of such a possibility of variation in the modeling of $B$-curves will make it possible to construct the most visible $B$ - surface modeling a system or object.

\section{SWOT analysis of research results}

Strengths. The model created in the CMGM is universal. This advantage has arisen due to the application of the generalizing technique of algebraic formation of characteristic functions. It is also important that the model can take into account any desired finite number of factors simulated. The solution of the problem in pointwise $B N$-calculus occurs on a spatial geometric figure, reflecting the behavior of the system, and the result of the decoupling can be projected on the axis or plane of the projections for the purpose of analysis. The solution of any problem of an n-dimensional space $E^{n}$ can always be decomposed into $\mathrm{n}$ one-dimensional solutions for analysis. The results of the analysis of one-dimensional solutions are easily synthesized in the $n$-dimensional model of the system. Since in a pointwise $B N$-multiple solution of the problem occurs relative to the base points of the geometric figure, the displacement of the geometric figure does not require a conversion to the decoupling. That is, the absence of position parameters relative to the global coordinate system greatly simplifies the calculations, especially when the initial data is partially changed. Such opportunity will significantly reduce the time and reduce the cost of modeling complex multifactor systems. This concerns multifactor modeling of real economic, technical and any other systems, as well as the activity of designing new systems. The model is quickly reconfigured when the mode of operation of the model is changed. Computer experiments will help to quickly analyze the activities in many indicators, in particular, management objects, make forecasts and make informed management decisions.

Weaknesses. The complexity of parametrization, the unconventionality of the method, is a deterrent to the use of CMGM. In particular, when implementing on real business objects, establishing correct parametric links in modeling is laborious, requires highly qualified specialists who are fully aware of all the nuances of the enterprise's work in terms of economics, technology and technology, energy consumption and the like.

Opportunities. Further development of CMGM and creation of special software, it implements, opens new opportunities in modeling of multifactor systems and processes. The use of geometric modeling of B-curves with $\mathrm{BN}$-coordinates obtained through a generalized technique for the formation of characteristic functions in the composite method provides the universality of the CMGM. A one-, two-, three-parameter $B$-curve can be considered in the n-dimensional Euclidean space $E^{n}$. As a result, CMGM can be used to solve problems in n-dimensional space, and the result can be decomposed into n one-dimensional projections, on which it is easy to analyze the decoupling. This opens wide prospects for application, in particular, in information systems supporting management decisions.

Threats. The limitation of the application of CMGM is the complexity of parametrization of geometric figures relative to the base points. Unusual approach, which is irrespective of the coordinate method, requires special skills of specialists, apply it in practice.

\section{Conclusions}

1. The principle of the formation of characteristic functions is the operation of multiplying parameters and artificially designed coefficients. As a result of the definition, the product at the node points becomes zero or one, and in the intervals between the node points it changes from zero to one. The number of factors of the characteristic function is equal to the number of nodal points, the characteristic function interpolates.

2. It is shown that each of the $B N$-coordinates is a fractional-rational function, taking values from zero to one.

3. It is determined that the $B N$-coordinates of one $B$-curve form a system of interconnected fractional-rational functions. A change in the value of one $B N$-coordinate entails corresponding changes in the remaining $B N$-coordinates, and the sum of all $B N$-coordinates, any value of the parameter $t$ from zero to one, will always be unity.

Thus, a generalizing technique for the algebraic formation of characteristic functions has been developed, the transition from characteristic functions to $\mathrm{BN}$-coordinates has been determined for the interpolation of three points. The technique used here can also be used for geometric interpolation of four or more points. The possibility of increasing the number of initial points of a geometric figure for BN-interpolation extends the capabilities of models of multifactorial processes, systems, etc.

\section{References}

1. Ivanov G. S. Konstruirovanie tekhnicheskikh poverkhnostey (matematicheskoe modelirovanie na osnove nelineynykh preobrazovaniy). Moscow: Mashinostroenie, 1987. 192 p.

2. Kotov I. I. Mgnovennye algebraicheskie preobrazovaniya i ikh vozmozhnye prilozheniya // Trudy Moskovskogo aviatsionnogo instituta. 1969. Issue 191. P. 71-83.

3. Obukhova V. S. Prikladnaya geometriya poverkhnostey otval'nogo tipa: proceedings // Respublikanskaya konferentsiya po prikladnoy geometrii i inzhenernoy grafike. Kyiv, 1976. P. 76-78.

4. Mykhailenko V. Ye., Kuchkarova D. F. Heometrychni modeli topohrafichnykh poverkhon v zadachakh proektuvannia // Prykladna heometriia ta inzhenerna hrafika. 1997. Issue. 62. P. 53-57.

5. Pavlenko O. M. Doslidzhennia tochnosti protsesu zghushchennia kryvoi skladenoi formy pry rekonstruktsii zasobamy tochkovoho chyslenni Baliuby-Naidysha // Prykladna heometriia ta inzhenerna hrafika. 2013. Issue 91. P. 206-210.

6. Bakhvalov N. S. On the optimality of linear methods for operator approximation in convex classes of functions // USSR Computational Mathematics and Mathematical Physics. 1971. Vol. 11, Issue 4. P. 244-249. doi: http://doi.org/10.1016/00415553(71)90017-6

7. Virchenko H. A. Proektuvannia ploskykh obvodiv z vykorystanniam kryvykh Bezie tretoho poriadku // Prykladna heometriia ta inzhenerna hrafika. 2003. Issue 72. P. 119-123.

8. Giannelli C., Hormann K., Zagar E. Recent trends in theoretical and applied geometry // Computer Aided Geometric Design. 2014. Vol. 31, Issue 7-8. P. 329-330. doi: http://doi.org/ 10.1016/j.cagd.2014.09.002 
9. Naidysh V. M., Baliuba Y. H., Vereshchaha V. M. Alhebra BN-yschyslenyia // Prykladna heometriia ta inzhenerna hrafika. 2012. Issue 90. P. 210-215. URL: http://elar.tsatu.edu.ua/ handle/123456789/2334

10. Konopatskyi Ye. V. Polishchuk V. I. Teoretychni osnovy tochkovoho vyznachennia poverkhon zi zminnym sympleksom // Naukovi notatky. 2008. Issue 22 (2). P. 276-281.

11. Tochechnoe yschyslenye heometrycheskykh form y eho mesto $\mathrm{v}$ riadu druhykh sushchestvuiushchykh yschyslenyy / Baliuba Y. H. et. al. // Kompiuterno-intehrovani tekhnolohiii: osvita, nauka, vyrobnytstvo. 2011. Issue 6. P. 24-29. URL: http:// ki.lutsk-ntu.com.ua/node/123/section/6

Adoniev Yevhen, PhD, Associate Professor, Department of Design and Information Technologies, Economics and Humanities Faculty of Zaporizhzhia National University, Melitopol, Zaporizhzhia region, Ukraine, e-mail: evgen.adoniev@gmail.com,ORCID: http://orcid.org/ 0000-0003-1279-4138

Naidysh Andrii, Doctor of Technical Sciences, Professor, Head of the Department of Applied Mathematics and Information Technologies, Bogdan Khmelnitsky Melitopol State Pedagogical University, Melitopol, Zaporizhzhia region, Ukraine, e-mail: nav1304@ukr.net ORCID: http://orcid.org/0000-0003-4057-7085

Vereschaga Viktor, Doctor of Technical Sciences, Professor, Department of Applied Mathematics and Information Technologies, Bogdan Khmelnitsky Melitopol State Pedagogical University, Melitopol, Zaporizhzhia region, Ukraine, e-mail: vervik49@gmail.com, ORCID: http://orcid.org/0000-0003-0038-8300 